\title{
APPLYING PBL AND ZUVIO TO ENHANCE ENGLISH
}

\section{LEARNING MOTIVATION}

\author{
Bor-Tyng Wang \\ Foreign Language Center, Feng-Chia University \\ NO. 100 Wen-hua Rd., Taichung, Taiwan \\ btwang.tw@gmail.com
}

\begin{abstract}
To inspire college students' English learning motivation, this study proposed to combine Project-Based Learning (PBL) with ZUVIO online teaching platform. The traditional teaching methods focus on teachers' direct instruction in class, which mean that students only receive knowledge from teachers instead of formulating the answers on their own. This also decreases interaction in the classroom and prevents students from collaborating with other peers. However, implementing PBL and ZUVIO would allow students to apply knowledge in the social context and work with their classmates. In this study, two freshman English classes in a private university in central Taiwan were chosen as the sample. The students in both classes were low-level students (CEF A2 level). One class $(\mathrm{N}=39)$ was chosen as the experimental group which had to complete the PBL tasks assigned by the teacher and use peer assessment function in ZUVIO for one academic year. The other class $(\mathrm{N}=43)$ was chosen as the control group which was given the traditional teaching instructions. The results showed that the experimental group performed better on the midterm exam compared to the control group during both semesters $(p=0.001$ ). Additionally, the results of the questionnaire showed that students' motivation to learn English increased when using PBL and ZUVIO as teaching methods.
\end{abstract}

Keywords: Project-Based Learning, ZUVIO, English Learning Motivation 


\section{INTRODUCTION}

With the development of modern technologies, multimedia has been widely used in the teaching field, exerting a great influence on classroom teaching (Ding \& $\mathrm{Li}, 2011$; Neo \& Neo, 2004). The learning styles have become more diverse to enhance both self-study and collaborative learning environment (Palloff \& Pratt, 2005). Nowadays, learners become more active when they use digital devices in the classroom, and the classroom also becomes more interactive because of the online instructions (Gilakjani, Ismail \& Ahmadi, 2011). However, students should not learn from the Internet. Instead, students should investigate and solve the problems with their peers as a team. Moreover, the "student-centered" approach, PBL, not only inspires students' active learning, but also enhances learner autonomy (Keengwe, Onchwari \& Onchwari, 2009). Moreover, PBL can be used to integrate and construct knowledge and to allow students to explore the problems in the real world. Therefore, this study aimed to explore the use of PBL and an online peer assessment system in ZUVIO to enhance students' English learning motivation. It was proposed that the two approaches would strengthen students' problem-solving ability, professional knowledge and teamwork abilities.

The study lasting for 1 year was conducted in Feng-Chia University located in central Taiwan. Two Freshman English classes were chosen as the sample. The students in both classes were at the same English level (CEF A2 level). One class ( $\mathrm{N}=39$ ), assigned to the experimental condition, was given the instructions with PBL and ZUVIO. On the other hand, the other class $(\mathrm{N}=43)$, which was the control group, was given the traditional teaching instructions.

\section{Research Questions}

To understand the effectiveness of PBL and ZUVIO in the Freshman English classroom, the following research questions were proposed:

(1) Can combining PBL and ZUVIO improve students' learning motivation?

(2) Can peer assessment inspire students' classroom engagement and teamwork spirit?

\section{LITERATURE REVIEW}

The following sections review the features of PBL, learning motivation, ZUVIO and peer assessment method. 


\section{Features of Project-Based Learning}

The main purpose of PBL is to support students' intrinsic motivation, inspire active learning and guide students to do self-study in a meaningful situation (Polman, 2000; Roessingh \& Chambers, 2011; Thomas, Mergendoller \& Michaelson, 1999). Polman (2000) mentioned that PBL could increase students' learning motivation and provide an authentic learning environment, that is, PBL is a "student-centered" approach. The teacher acts as a facilitator who guides questions in the classroom (Bell, 2010). Moreover, PBL curriculum design follows 6 criteria listed as follows (Thomas, 2000):

(1) PBL encourages students to carry out more discussions and in-depth investigation.

(2) In PBL, there is no correct answer. Instead, the assigned task guides students to achieve high-level thinking.

(3) PBL can cut into the field and the core of the topic to let students understand the questions.

(4) PBL tasks are challenging, challenging students' willingness to face the tasks, try new things and solve unfamiliar questions.

(5) PBL trains students to gain critical thinking ability.

(6) PBL enhances students' problem-solving ability.

In addition, with the new technology, students can use the Internet on various electronic devices to investigate, inquire about, and look for answers through PBL process (ChanLin, 2008). In short, to develop a perfect PBL curriculum, teachers need to set teaching goals and choose appropriate assessment methods. Next, teachers need to check the resources they can use in the classroom and consider students' prior knowledge. Subsequently, the students can work on the projects and create group presentations in class (Wang, Teng \& Lin, 2015).

Compared to the traditional assessment methods, the assessment methods of PBL are quite diverse, including portfolios, presentations, reports, and so on (Bell, 2010; Wang, Teng \& Lin, 2015). Hence, in this study, the online peer assessment tool was used to evaluate students' learning outcomes.

\section{PBL and Learning Motivation}

According to some previous studies on PBL, the learning has the following functions (Moursund, 1999; Thomas, 2000):

(1) Enhance learning motivation 
(2) Integrate and construct knowledge

(3) Increase collaborative opportunities

(4) Cultivate abilities, like problem-solving ability, communicative ability, and the like

In addition, PBL can motivate students to learn and enhance students' soft-skills, like communication, teamwork or problem-solving skills (Surif, Ibrahim \& Mokhtar, 2013). Blumenfeld et al. (1991) first discussed PBL's effect on student motivation, and they pointed out several aspects to be considered in PBL. The first aspect is the authenticity of the project, that is, when students face authentic problems, they are more motivated to solve the problems because they can really experience the problems in their daily life. In addition, students focus on interest and value of the projects (Blumenfeld et al., 1991). Students like the project to be a bit beyond their level; they need freedom to choose the project, and then they can complete the project with high motivation.

Barron et al. (1998) thought that the outcome of the project has to be considered as well. Through this aspect, we can observe students' teamwork and check if they are responsible for themselves. In addition, Bradford (2005) found that PBL provides hands-on and authentic learning environment, which can motivate students. Helle et al. (2007) reported similar findings regarding the PBL effect on students' motivation. They interviewed students and found that the course motivated students. They pointed out that PBL course design needs to consider- authenticity, students' involvement, students' sense of ownership, and teamwork skills. In short, the PBL-setting of the course can increase students' motivation.

\section{ZUVIO}

ZUVIO is an online teaching and learning platform designed by Xue-Yue Technology in 2013 (ZUVIO, 2013). It aims to improve teaching quality, increase students' learning motivation, and use digital educational system (Yan, 2014). Figure 1 shows the interface of ZUVIO platform.

According to Fig. 1, the features of ZUVIO are summarized as follows (ZUVIO, 2013):

(1) Course and account management system: Teachers can offer different courses each semester and manage the enrollment of each course.

(2) Multimedia question system: Teachers can develop multiple choices, open-ended questions, or group questions. In addition, figures can be included in the questions. 
Moreover, teachers can decide whether the individual student or the group should answer the questions. Students, could use digital devices, like smartphones, tablets, or computers, to answer questions immediately.

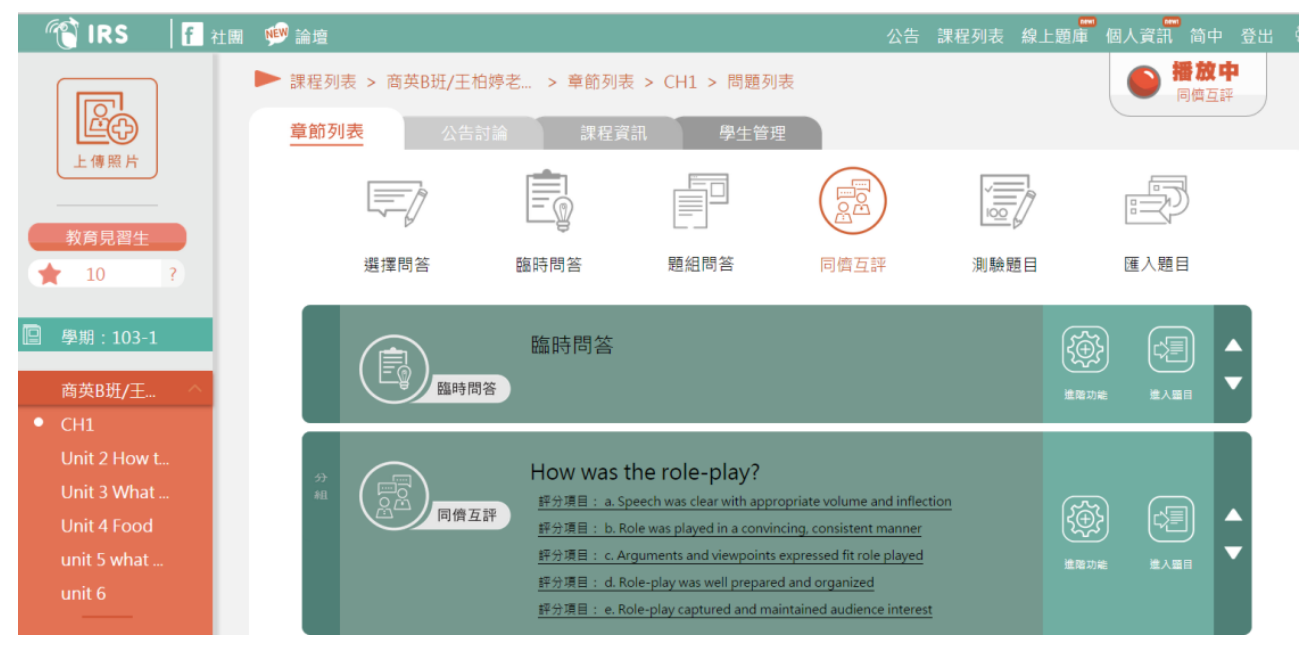

Figure 1 The Interface of ZUVIO

(3) Peer assessment system: Teachers can create groups and students can conduct peer assessment. Meanwhile, grading rubrics and weighting can be set in the system. Besides, teachers can choose whether the students have to give comments. During the peer assessment, the system will update scores and rankings among individuals or groups.

(4) Grading system: Teachers can observe the dynamic answer process, and receive the detailed data and figures. Students, on the other hand, can read the previous answering records to review the course.

\section{Peer Assessment}

Peer assessment means that learners with the same background assess their peers' performance as instructors (Falchikov, 2007; Topping, 1998). Peer assessment can improve the quality of learning process, train students' critical thinking ability, and enhance the learner autonomy (Bhalerao \& Ward, 2001; Boud, 2007; Falchikov, 2007). However, the participants in peer assessment may have different opinions, which can result in conflicting cognition ( $\mathrm{Yu} \& \mathrm{Wu}, 2011$ ). Under the conflicting cognition, participants revise their views to construct knowledge that is more accurate (Topping, 
1998).

Peer assessment has broad effect on other areas, including cognition and metacognition, affect, social and transferable skills, and systemic benefits (Evans, 2013; Topping, 1998).

(1) Cognition and metacognition: Assessors will go through the processes of thinking, comparing, contrasting, and communicating while they are reviewing others' articles. Therefore, the original understanding may be more consolidated or reinforced. Concerning the candidates, when their ideas or projects are questioned, they can obtain beneficial feedback. Additionally, they can self-reflect, or clarify misconceptions.

(2) Affect: At the beginning, both the reviewer and candidate are anxious. Gradually, the peer assessment helps them have a sense of responsibility and evaluation motivation.

(3) Social and transferable skills: Peer assessment encourages teamwork skills and promotes active learning. In addition, it also helps individuals improve communicative skills coordinating skills, and strategies.

(4) Systemic benefits: Peer assessment provides deeper insights for learners within the standard assessment process. Moreover, peer assessment brings confidence and tolerance to learners during the evaluation process.

\section{RESEARCH DESIGN}

The participants, instruments, and procedure of the study are introduced in this section.

\section{Participants}

Two freshman English classes participated in this study lasting for 1 year. In total, eighty-two Taiwanese freshman did not declare their major. One class $(\mathrm{N}=39)$ was chosen as the experimental group, which had to complete the PBL tasks assigned by the teacher and use peer-review function in ZUVIO. The other class $(\mathrm{N}=43)$ was chosen as the control group, which was given the traditional teaching instructions. The same English teacher taught both classes, and the students in both classes were low-level students (CEF A2 level). 


\section{Instruments}

In this study, the student's t-test was used to compare the two classes' in Freshman English midterm exam scores for 2 semesters. In addition, a five-point questionnaire (one being the lowest and five being the highest) was distributed to measure students' attitudes toward PBL and ZUVIO. The questionnaire used in this study included 18 questions (please see Appendix 1) and covered four categories: collaborative motivation (items 1 to 3), PBL curriculum (items 4 to 6), learning outcomes (items 7 to 10), and ZUVIO peer assessment system (items 11 to 18).

\section{Procedure}

First, two freshman English classes were chosen to participate in this study. Both of them were at the same English level $(\mathrm{CEF}=\mathrm{A} 2)$ based on their English scores on the college entrance exam. They were taught by the same instructor. Since students' English ability was the same, the instructor chose one class as a control group $(\mathrm{N}=43)$ and the other as the experimental group $(\mathrm{N}=39)$ randomly. The instructor used traditional teaching method to teach English in the control group. However, the experimental group was taught with PBL and ZUVIO peer assessment methods (please see Figure 2 and Figure 3). The ZUVIO survey was not conducted anonymously because the students in the experimental group were divided into different groups, and they had to sign their names on the ZUVIO questionnaire.

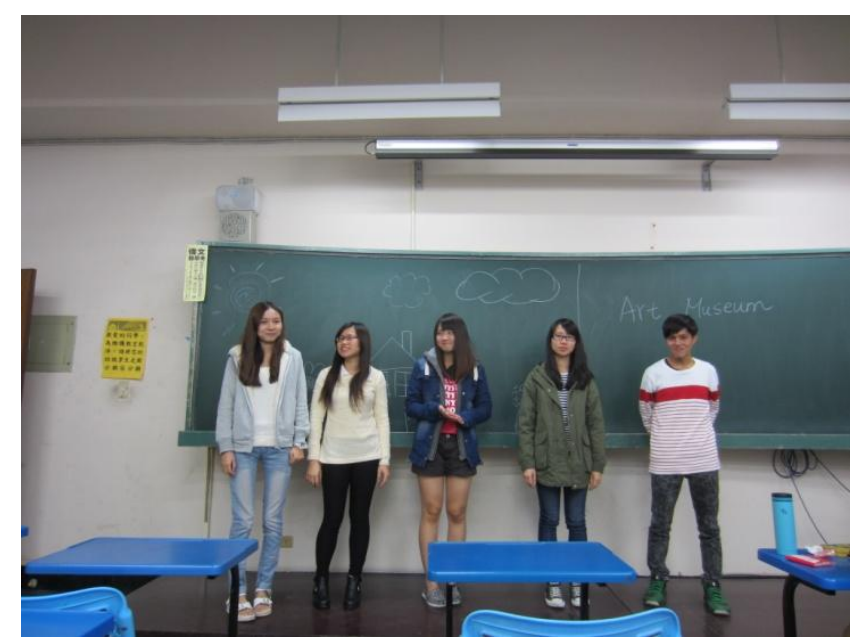

Figure 2 Role-Play of the Experimental Group 


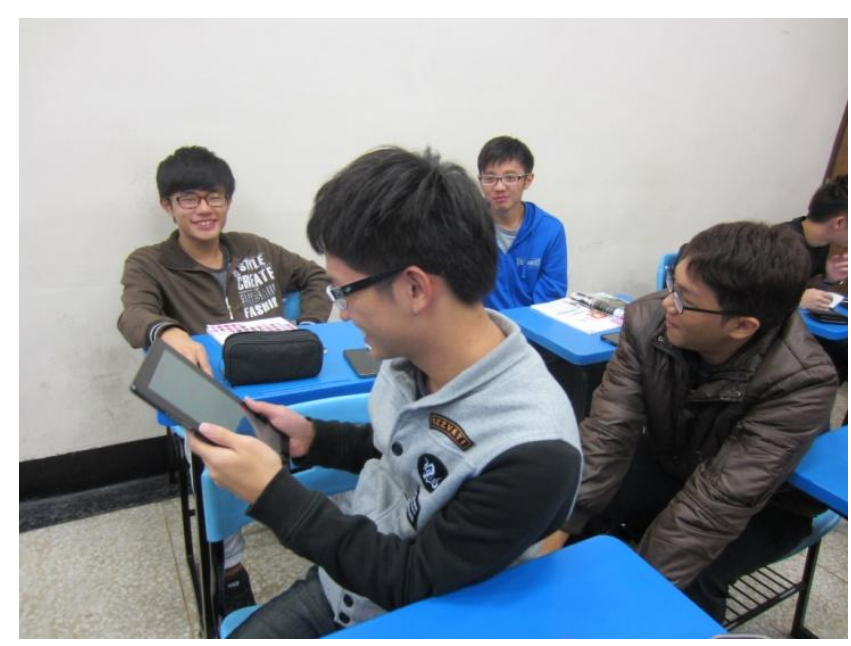

Figure 3 Students Used ZUVIO Peer Assessment System in Class

After the lecture, both groups of students took the same Freshman English midterm exam in semester 1 and semester 2 (total: 1 year). In addition, the experimental group had to fill out the PBL and ZUVIO questionnaire. The procedure of this study is shown in Figure 4.

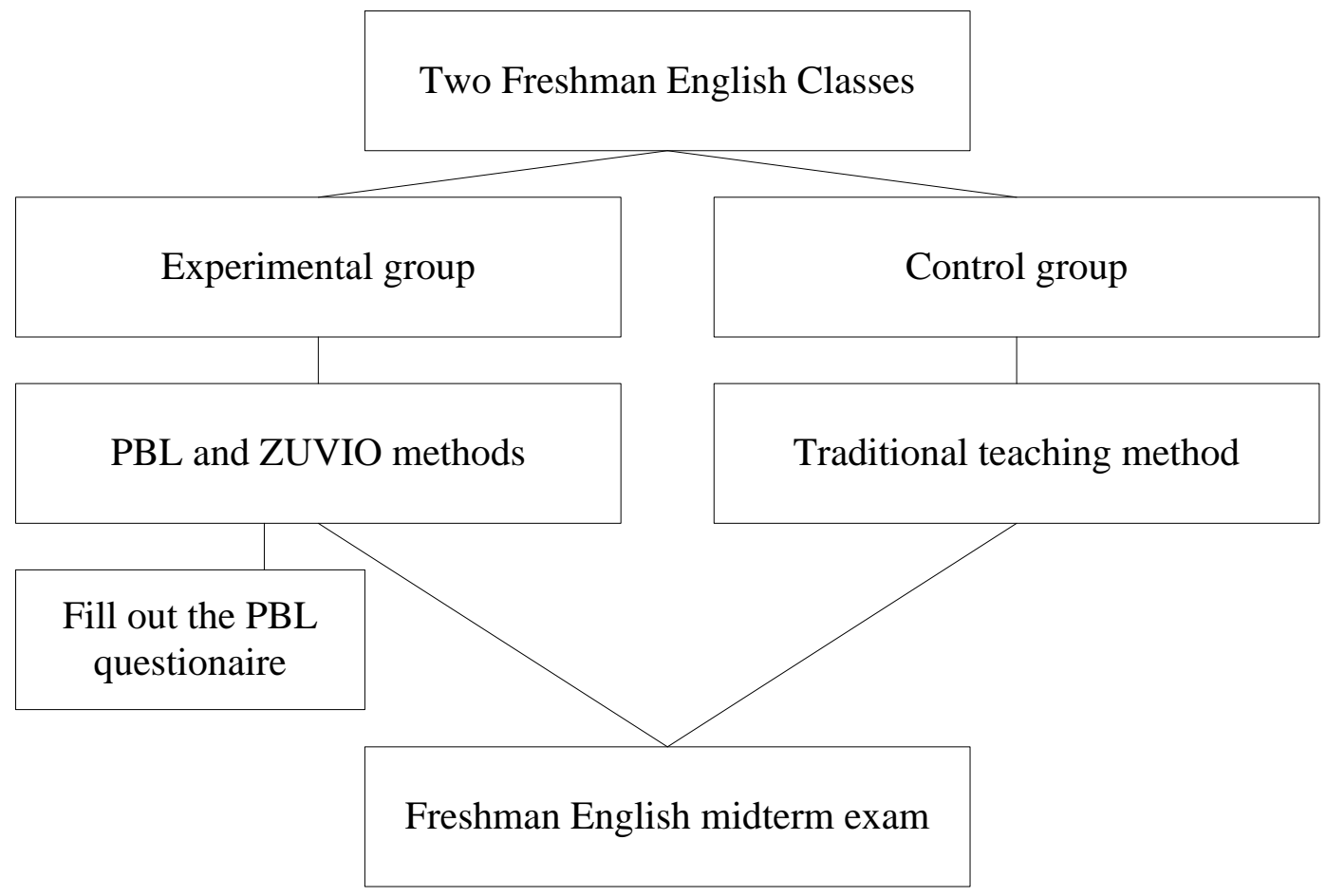

Figure 4 The Procedure of This Study 


\section{RESULTS AND DISCUSSIONS}

According to the unified Freshman English midterm exam results for 2 semesters, the experimental group and the control group differed significantly in the scores ( $p=.001$ $<.05$ ) with regard to the use of PBL teaching strategy (please see Table 1 and Table 2).

Table 1 Student's T-test in Semester One

\begin{tabular}{ccccc}
\hline Class & N & M & SD & Sig. (one-tailed) \\
\hline Experimental group & 39 & 81.95 & 1.64 & .001 \\
Control group & 43 & 77.25 & 6.35 & \\
\hline
\end{tabular}

Table 2 Student's T-Test in Semester Two

\begin{tabular}{ccccc}
\hline Class & N & M & SD & Sig. (one-tailed) \\
\hline Experimental group & 39 & 82.24 & 10.43 & .001 \\
Control group & 43 & 74.00 & 13.06 & \\
\hline
\end{tabular}

Therefore, we can assume that implementing PBL in the English classroom ican enhance students' learning outcomes.

Next, to understand students' attitude toward PBL and ZUVIO, a questionnaire (please see Appendix 1) was distributed to the experimental group. The Cronbach's reliability of the questionnaire was 0.741 , which indicated good reliability of the questionnaire. Moreover, the results of the questionnaire are shown in Table 3.

Table 3 indicates four major findings. First, the mean scores of items 1 to 3 were high, implying that the students were willing to help each other during the project, and they could reach a consensus. Second, with regard to students' attitude towards PBL curriculum, the results showed that students liked to try new things, and most of them agreed that they could use the knowledge in other classes (see items 4 to 6). Third, most students were satisfied with the learning outcomes, and they noticed that the learning process was also important. Finally, they had positive responses to ZUVIO peer assessment system and believed that the class has become more interesting (please see Figure 5). 
Table 3 Results of the Questionnaire

\begin{tabular}{|c|c|c|}
\hline Items & Mean & S.D. \\
\hline 1. I learned something useful in the project. & 4.47 & .56 \\
\hline 2. During the project, I listened carefully to my partner's ideas. & 4.60 & .78 \\
\hline We encouraged each other while doing the project. & 4.63 & .49 \\
\hline $\begin{array}{l}\text { 4. In English class, I like the challenging content because this helps me achieve } \\
\text { new knowledge. }\end{array}$ & 4.70 & .47 \\
\hline 5. I think I can apply what I've learned in the English class to other classes. & 4.53 & .57 \\
\hline 6. I think PBL is useful in learning English. & 4.60 & .56 \\
\hline 7. Understanding the assigned project is important to me. & 4.67 & .48 \\
\hline 8. I am confident to obtain high scores in Freshman English class. & 4.67 & .55 \\
\hline $\begin{array}{l}\text { 9. Nothing is more important than getting high grades; therefore, grades are my } \\
\text { only concern in Freshman English class. }\end{array}$ & 4.63 & .49 \\
\hline 10. I am satisfied with the outcome of the assigned project. & 4.52 & 62 \\
\hline 11. Using peer assessment system in ZUVIO doesn't make me feel bored. & 4.49 & 62 \\
\hline $\begin{array}{l}\text { 12. Comparing with the traditional grading method (i.e. the teacher gives } \\
\text { scores), ZUVIO's peer assessment system makes me feel bored. }\end{array}$ & 1.85 & 61 \\
\hline 13. I hope the teacher can use ZUVIO more in class assessments. & 4.55 & .62 \\
\hline 14. I like the multi-media assessment system in class. & 4.61 & .66 \\
\hline $\begin{array}{l}\text { 15. I think the ZUVIO peer assessment system can increase my curiosity in this } \\
\text { course. }\end{array}$ & 4.46 & 67 \\
\hline $\begin{array}{l}\text { 16. I think I can pay more attention to each group's presentation with the use of } \\
\text { ZUVIO peer assessment system. }\end{array}$ & 4.58 & 61 \\
\hline $\begin{array}{l}\text { 17. I think the in-class presentation becomes more interesting with the use of } \\
\text { ZUVIO peer assessment system. }\end{array}$ & 4.61 & 61 \\
\hline 18. I would like to learn more about the ZUVIO system. & 4.75 & 62 \\
\hline
\end{tabular}

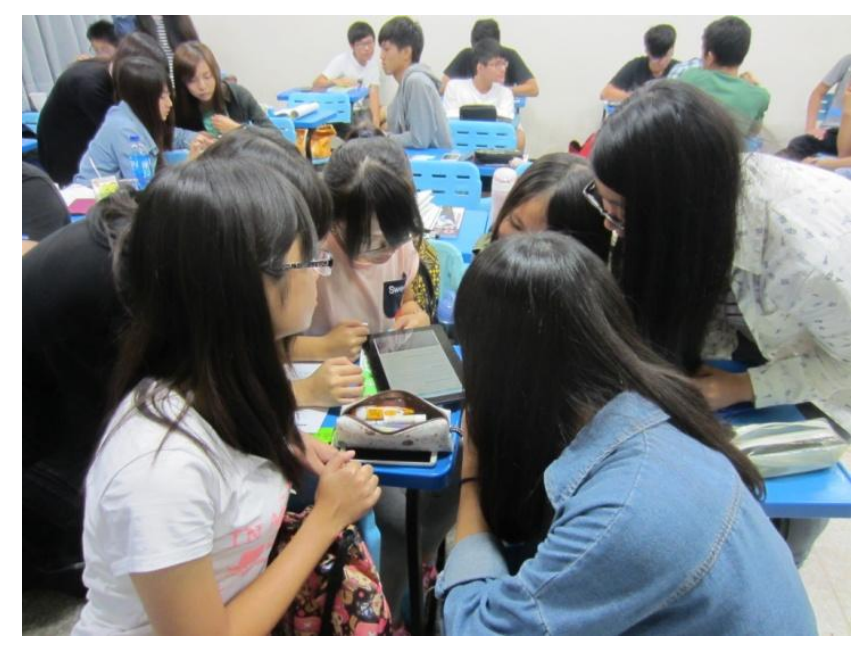

Figure 5 Students' Discussion on Peer Assessment Scores 


\section{CONCLUSIONS AND IMPLICATIONS}

The implementation of PBL and ZUVIO in the Freshman English classroom had effective and positive feedback in the Taiwanese classroom. According to the results of the questionnaire, students' learning motivation has been enhanced. Moreover, they were willing to apply what they have learned, solve problems, and think critically. The student-centered approach guided the students to be more active in the classroom, and the PBL curriculum also created an interactive learning atmosphere. In addition, with the use of ZUVIO online peer assessment platform, students could work with others on the Internet. Based on the results of the questionnaire, students could listen to their team members' ideas and try to reach a consensus. They paid more attention to the group presentation because they can grade their classmates.

This study has several implications. 1) Using PBL helps students' English learning skills and collaborative skills. 2) Multiple-grading methods increase students' involvement in the class. Students feel positive when they can grade their peers. 3) Combing ZUVIO's peer assessment system with the group presentation creates an interactive classroom.

The limitations of the study were that only two classes participated in this study. The results would be more valid if there were more participants. Besides, if the study lasted longer, students' learning motivation and learning behavior could be observed more clearly. In the future, more teaching approaches could be implemented with multimedia to create interactive and student-centered classrooms.

\section{ACKNOWLEDGEMENTS}

An earlier version of this paper was presented at the e-CASE \& e-Tech 2015 conference, held in Kuala Lumpur, Malaysia, April 1-3, 2015, and published in the conference proceedings.

\section{REFERENCES}

Barron, B., Schwartz, D., Vye, N., Moore, A., Petrosino, A., Zech, L., \& Bransford, J. (1998). Doing with understanding: lessons from research on problem- and project-based learning. The Journal of the Learning Sciences, 7(3), 271-311. http://dx.doi.org/10.1080/10508406.1998.9672056.

Bell, S. (2010). Project-based learning for the $21^{\text {st }}$ century: skills for the future. The 
Clearing House, 83(2), 39-43.

Bhalerao, A., \& Ward, A. (2001). Towards electronically assisted peer assessment: a case study. ALT-J Research in Learning Technology, 9(1), 26-37. http://dx.doi.org/10.1080/00098650903505415.

Blumenfeld, P., Soloway, E., Marx, R., Krajcik, J., Guzdial, M., \& Palincsar, A. (1991). Motivating project-based learning: Sustaining the doing, supporting the learning. Educational Psychologist, 26(3), 369-398. http://dx.doi.org/10.1080/00461520.1991.9653139.

Boud, D. (2007). Reframing assessment as if learning were important. In D. Boud \& N. Falchikov (Eds.), Rethinking assessment in higher education: Learning for the longer term (pp. 14-25). London: Routledge. http://dx.doi.org/10.4324/9780203964309.

Bradford, M. (2005). Motivating students through project-based service learning. T.H.E. Journal, 32(6), 29-30.

ChanLin, L.J. (2008). Technology integration applied to project-based learning in science. Innovations in Education and Teaching International, 45(1), 55-65. http://dx.doi.org/10.1080/14703290701757450.

Ding, M., \& Li, H. (2011). On the application of multimedia in economics teaching. Interactional Educational $\quad$ Studies, $\quad 4(3), \quad 88-90$. http://dx.doi.org/10.5539/ies.v4n3p88.

Evans, C. (2013). Making sense of assessment feedback in higher education. Review of Educational Research, 83(1), 70-120. http://dx.doi.org/10.3102/0034654312474350.

Falchikov, N. (2007). The place of peers in learning and assessment. In D. Boud \& N. Falchikov (Eds.), Rethinking assessment in higher education for the longer term (pp. 128-143). London: Routledge. http://dx.doi.org/10.4324/9780203964309.

Gilakjani, A.P., Ismail, H.N., \& Ahmadi, S.M. (2011). The effect of multimodal learning models on language teaching and learning. Theory and Practice in Language Studies, 1(10), 1321-1327. http://dx.doi.org/10.4304/tpls.1.10.1321-1327.

Helle, L., Tynjälä, P., Olkinuora, E., \& Lonka, K. (2007). 'Ain’t nothin' like the real thing', motivation and study processes on work-based project course in information systems design. British Journal of Educational Psychology, 77(2), 397-411.

Keengwe, J., Onchwari, G., \& Onchwari, J. (2009). Technology and student learning: toward a learner-centered teaching model. AACE Journal, 17(1), 11-22. 
Moursund, D.G. (1999). Project-based learning in an information technology environment. Eugene, OR: ISTE.

Neo, T.K., \& Neo, M. (2004). Integrating multimedia into the Malaysian classroom: Engaging students in interactive learning. The Turkish Online Journal of Educational Technology, 3(3), 31-37.

Palloff, R.M., \& Pratt, K. (2005). Collaborating online: Learning together in community. San Francisco, CA: Jossey-Bass.

Polman, J.L. (2000). Designing project-based science: Connecting learners through guided inquiry. New York: Teacher's College Press.

Roessingh, H., \& Chambers, W. (2011). Project-based learning and pedagogy in a teacher preparation: staking out the theoretical mid-ground. International Journal of Teaching and Learning in Higher Education, 23(1), 60-71.

Surif, J., Ibrahim, N.H., \& Mokhtar, M. (2013, July). Implementation of problem based learning in higher education institutions and its impact on students' learning. Paper presented at the 4th International Research Symposium on Problem-Based Learning, Kuala Lumpur, Malaysia.

Thomas, J.W. (2000). A review of research on project-based learning. San Rafael, CA: Autodesk Foundation.

Thomas, J.W., Mergendoller, J.R., \& Michaelson, A. (1999). Project-based learning: A handbook for middle and high school teacher. Novato, CA: The Buck Institute for Education.

Topping, K.J. (1998). Peer assessment between students in colleges and universities. Review of Educational Research, 68(3), 249-276. http://dx.doi.org/10.3102/00346543068003249.

Yan, L.Q. (2014, November 25). ZUVIO IRS software: No distance between teachers and students. Retrieved from http://www.bnext.com.tw/article/view/id/31579.

Yu, F.Y., \& Wu, C.P. (2011). Different identity revelation modes in an online peer-assessment learning environment: effects on perceptions toward assessors, classroom climate and learning activities. Computers \& Education, 57(3), 2167-2177. http://dx.doi.org/10.1016/j.compedu.2011.05.012.

Wang, B.T., Teng, C.W., \& Lin, Y.H. (2015). Let's go traveling-project-based learning in a Taiwanese classroom. International Journal of Information and Education Technology, 5(2), 84-89. http://dx.doi.org/10.7763/IJIET.2015.V5.481. 
ZUVIO. (2013, October 15). ZUVIO. Retrieved from http://www.zuvio.tw/.

\section{APPENDIX 1: PBL and ZUVIO Questionnaire}

The following questionnaire is designed to gather your feedback about the PBL and ZUVIO. Please check the choice $(5=$ strongly agree, $4=$ agree, $3=$ neutral, $2=$ disagree, $1=$ strongly disagree).

Part I. collaborative motivation

1. I learned something useful in the project.

$$
5 \square \quad 4 \square \quad 3 \square \quad 2 \square \quad 1 \square
$$

2. During the project, I listened carefully to my partner's ideas.

$$
5 \square \quad 4 \square \quad 3 \square \quad 2 \square \quad 1 \square
$$

3. We encouraged each other while doing the project.

$$
5 \square \quad 4 \square \quad 3 \square \quad 2 \square \quad 1 \square
$$

Part II. PBL curriculum

4. In English class, I like the challenging content because this helps me achieve new knowledge.

$5 \square \quad 4 \square \quad 3 \square \quad 2 \square \quad 1 \square$

5. I think I can apply what I've learned in the English class to other classes. $5 \square \quad 4 \square \quad 3 \square \quad 2 \square \quad 1 \square$

6. I think PBL is useful in learning English.

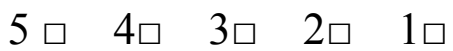

Part III. Learning Outcomes

7. Understanding the assigned project is important to me.

$$
5 \square \quad 4 \square \quad 3 \square \quad 2 \square \quad 1 \square
$$

8. I am confident to obtain high scores in Freshman English class. $5 \square \quad 4 \square \quad 3 \square \quad 2 \square \quad 1 \square$

9. Nothing is more important than getting high grades; therefore, grades are my only concern in Freshman English class.

$$
5 \square \quad 4 \square \quad 3 \square \quad 2 \square \quad 1 \square
$$

10. I am satisfied with the outcome of the assigned project.

$$
5 \square \quad 4 \square \quad 3 \square \quad 2 \square \quad 1 \square
$$


Part VI. ZUVIO peer assessment system

11. Using peer assessment system in ZUVIO doesn't make me feel bored. $5 \square \quad 4 \square \quad 3 \square \quad 2 \square \quad 1 \square$

12. Comparing with the traditional grading method (i.e. the teacher gives scores), ZUVIO's peer assessment system makes me feel bored.

$5 \square \quad 4 \square \quad 3 \square \quad 2 \square \quad 1 \square$

13. I hope the teacher can use ZUVIO more in class assessments. $5 \square \quad 4 \square \quad 3 \square \quad 2 \square \quad 1 \square$

14. I like the multi-media assessment system in class.

$5 \square \quad 4 \square \quad 3 \square \quad 2 \square \quad 1 \square$

15. I think the ZUVIO peer assessment system can increase my curiosity in this course. $5 \square \quad 4 \square \quad 3 \square \quad 2 \square \quad 1 \square$

16. I think I can pay more attention to each group's presentation with the use of ZUVIO peer assessment system. $5 \square \quad 4 \square \quad 3 \square \quad 2 \square \quad 1 \square$

17.I think the in-class presentation becomes more interesting with the use of ZUVIO peer assessment system.

$5 \square \quad 4 \square \quad 3 \square \quad 2 \square \quad 1 \square$

18. I would like to learn more about the ZUVIO system.

$5 \square \quad 4 \square \quad 3 \square \quad 2 \square \quad 1 \square$ 
